\title{
KEDUDUKAN AHLI WARIS YANG PENERIMA HIBAH DARI ORANG TUA TERHADAP AHLI WARIS LAINNYA PADA PROSES PEMBAGIAN WARIS
}

\author{
Umar Haris Sanjaya, Muhammad Yusuf Suprapton \\ Fakultas Hukum Universitas Islam Indonesia \\ Email: umarharis@uii.ac.id, muhamadyusufsup@gmail.com
}

\begin{abstract}
Abstrak
Penelitian ini memfokuskan pada penjelasan tentang keberadaan dari ahli waris yang telah mendapatkan hibah dari orang tua semasa hidupnya, sehingga ahli waris yang lainnya dan belum menerima hibah menganggap penerima hibah tidak berhak untuk mendapatkan harta warisan lagi dari orang tuanya. Penelitian ini memuat rumusan masalah yang bagaimana kedudukan ahli waris penerima Hibah terhadap ahli waris lainnya dalam harta warisan pada perspektif hukum, apakah penerima hibah terhalang untuk menerima warisan ?. Hasil penelitian menjelaskan bahwa pengertian hibah dari 3 perspektif hukum perdata yaitu perdata barat (KUHPerdata), adat, dan fiqih islam (KHI) menjelaskan bahwa penerima hibah dari orang tua diperhitungan sebagai harta warisan, tetapi kedudukan mereka tidak terhalang untuk dapat menerima harta warisan. Sepatutnya para ahli waris bermusyawarah terlebih dahulu untuk mengutarakan keberadaan ahli waris yang sebelumnya menerima hibah untuk diperjelas bagiannya ketika membahas warisan. Sehingga ketika dibuat surat keterangan pembagian harta warisan tidak ada lagi ahli waris yang disimpangi dalam pengurusan harta warisannya.
\end{abstract}

Kata kunci : Hibah, Warisan

\begin{abstract}
This research focused on the clarification in the meaning of legal status of the heir which is the heir received the donation (grant) from the parents before. In fact, the other heirs does not recognize the position of donation receiver to gets inheritance rights belong to parents. This research using context of probles as how the legal status of the heir (donation receiver) belong to the other heirs in receiving inheritance, is the donation receiver does not has rights in inheritance. Research result found that meaning of donation in the 3 perspective of private law giving the similar consequences, thus are based on private law (civil code), adat law, and islamic fiqih law (KHI). Those are giving perspective that donation is recognized as the inhertance. And the legal status of receiver donation is available to receive inheritance.
\end{abstract}

Keywords : Donation, Inheritance

\section{A. PENDAHULUAN}

\section{Latar Belakang}

Permasalahan waris dan hibah masih menjadi penyebab timbulnya sengketa di masyarakat, hal ini memungkinkan terjadi karena mereka belum memahami tentang waris secara mendalam. Terkadang permasalahan waris dan hibah ini dipandang kurang begitu penting dalam kaidah keilmuan, mengingat masalah itu dianggap sebagai sesuatu yang lumrah dalam kehidupan. ${ }^{1}$ Tetapi begitu timbul sengketa dimasyarakat akan hal itu,

1 Hadis Nabi Muhammad SAW. 
mereka tidak tahu cara penyelesaiannya secara damai, sehingga sengketa tersebut menjadi sengketa hukum yang dibawa ke ranah gugatan di pengadilan. ${ }^{2}$ Maksud diatas sedikit mengutip dari hadis Nabi Muhammad SAW yang artinya "pelajarilah Al-quran dan ajarkanlah kepada manusia, pelajarilah faraid dan ajarkanlah kepada manusia karena aku adalah manusia yang pada suatu ketika mati ilmupun akan hilang dan hampir dua orang bersengketa dalam faraid dan masalahnya dan mereka tidak menjumpa orang yang memberitahu bagaimana penyelesaiannya" (H.R Ahmad, Tirmidzi, dan Nasa'i).

Hibah adalah kajian yang terkait dengan masalah waris, karena itu berhubungan dengan harta benda dari pemberi hibah ${ }^{3}$ sehingga bila pemberi hibah meninggal maka ia akan berganti menjadi seorang pewaris. ${ }^{4}$ Terhadap hal ini maka harta benda yang telah dihibahkan tersebut menjadi hitungan dalam suatu masalah kewarisan sehingga seorang penerima hibah pasti akan terlibat dalam masalah pembagian waris.

Pemahaman masyarakat terhadap hubungan hibah dan waris disini sering menimbulkan perbedaan pendapat, perbedaan tersebut kemudian yang akhirnya menjadikan suatu sengketa. Sebaik-baik penyelesaian sengketa dalam suatu permasalahan waris adalah dilakukan dengan cara perdamaian. Damai adalah cara yang direkomendasikan sesuai dengan perintah dalam Surat An-Nisa ayat 1 memberikan gambaran untuk selalu memelihara hubungan silaturahmi (kekeluargaan). Penyelesaian secara damai ini diartikan dengan tetap menjaga hubungan silaturahmi dalam konteks, hukum itu lebih bermaksud kepada penyelesaian secara mediasi. Karena penyelesaian secara damai ini tentunya efektif dan efisien serta tidak sampai ranah di pengadilan. ${ }^{5}$ Saat ini masyarakat awam masih menganggap bahwa penyelesaian sengketa di pengadilan masih dipandang kurang bijaksana pada konteks waris. Untuk dapat menjelaskan itu, maka perlu kiranya dijelaskan tentang hibah dan waris secara analisis dikaitkan pada suatu fakta yang bersinggungan antara hibah dan waris.

Masalah kewarisan sendiri sebagai bidang umum dalam masalah hibah diatur pada Kompilasi Hukum Islam pasal 171 huruf a yang bunyinya hukum kewarisan adalah hukum yang mengatur tentang pemindahan hak pemilikan harta peninggalan (tirkah) pewaris, menentukan siapa-siapa yang berhak menjadi ahli waris dan berapa bagiannya masing-masing sedangkan mengapa terkait dengan hibah karena ada hubungan pemberian dari seseorang (si pemberi) kepada orang lain. Pada saat pemberi hibah itu meninggal maka posisi pemberi hibah menjadi pewaris.

\footnotetext{
2010, hlm. 15

3 Effendi Perangin, Hukum Waris, Ctk. Pertama, Jakarta: PT. RajaGrafindo Persada, 1997, hlm. $20-23$

4 Sudikno Mertokusumo, Mengenal Hukum, Ctk. Ke-4, Yogyakarta: Liberty Yogyakarta, 2008, hlm. 167

5 Sri Wardah dan Bambang Sutiyoso, Hukum Acara Perdata dan Perkembangannya Di Indonesia, Ctk. Pertama, Yogyakarta: Gama Media, 2007, hlm. 80-90
}

2 Zainuddin Ali, Pelaksanaan Hukum Waris Di Indonesia, Ctk. Kedua, Jakarta: Sinar Grafika, 
Masalah waris dijelaskan pula dalam kajian hukum adat hanya dalam, hukum adat waris sedikit berbeda diartikan. Waris dijelaskan dengan proses peralihan harta yang dapat dimulai sejak pewaris hidup sehingga terhadap kematian bukan merupakan syarat yang mutlak untuk terjadinya waris. ${ }^{6}$ Kitab Undang-Undang Hukum Perdata mengatur masalah waris yang artinya adalah peralihan harta kekayaan yang ditinggalkan oleh seorang pewaris dengan segala akibatnya bagi ahli waris. ${ }^{7}$

Dari pengertian masalah pewarisan perlu kita beri sedikit ulasan singkat tentang hibah. Masalah hibah dalam Islam dijelaskan dengan memberikan hak miliknya kepada orang lain tanpa adanya harapan jasa atau imbalan. Bila itu dilakukan tanpa suatu imbalan maka hibah harus dilakukan bukan untuk sebuah balas jasa, atau ganti kerugian akibat kejadian terdahulu sehingga merasa ada kerugian yang kemudian diganti dengan hibah. ${ }^{8}$ Hibah dalam Islam lebih cenderung mengharap ridha Allah SWT yang dilakukan karena suatu kerelaan. Oleh karena itu, hibah dalam islam dapat dikatakan sebagai pemberian hadiah dan sedekah, semua itu ditujukan karena kita memuliakan seseorang atau karena hendak membantu seseorang. ${ }^{9}$

Dalam hukum perdata sendiri hibah diatur pada pasal 1666 Kitab Undang-Undang Hukum Perdata yang bunyinya, penghibahan adalah suatu persetujuan dengan mana seorang penghibah menyerahkan suatu barang secara cuma-cuma tanpa dapat menariknya kembali, untuk kepentingan seseorang yang menerima penyerahan barang itu. Undang-Undang hanya mengakui penghibahan-penghibahan antara orang-orang yang masih hidup. ${ }^{10}$ Dalam hukum adat sendiri hibah dijelaskan dengan suatu pembagian dari harta peninggalan seorang pemilik yang masih hidup yang diberikan kepada keluarganya. ${ }^{11}$

Dari gambaran terhadap waris dan hibah sendiri semuanya sama-sama membicarakan tentang pengalihan harta, dimana yang satunya dilakukan saat masih hidup (hibah) dan satunya dialihkan saat seseorang telah meninggal, namun semua kajian itu sama yaitu tentang pengalihan harta. Yang menjadi kajian penulis adalah bagaimana, bila seseorang yang telah menerima hibah dari orang tuanya, lalu ketika orang tua itu meninggal apakah si penerima hibah tersebut hendaknya menerima harta warisan lagi, mengingat masih ada ahli waris yang belum menerima harta dari orang tuanya. Pada tulisan ini, penulis akan menggambarkan kajian tersebut dengan sebuah kasus yang terjadi perselisihan paham dalam kajian hibah dan waris.

6 Sekar Maya, Hukum Waris Kekeluargaan Adat, Depok: Fakultas Hukum Universitas Indonesia, 2013, hlm. 30-35 hlm. 25

Munir Fuady, Konsep Hukum Perdata, Ctk. Pertama, Jakarta: Raja Grafindo Persada, 2014,

8 Helmi Karim, Fiqh Muamalah, Jakarta: Raja Grafindo Persada, 1997, hlm.70-74

9 Ramon Menik Siregar, "Fungsi Hibah Dalam Perlindungan Bagi Anak Pada Pembagian Harta di Tinjau Dari Hukum Perdata”, Skripsi, Medan: Universitas Sumatera Utara, 2008, hlm. 17

10 Kitab Undang-Undang Hukum Perdata pasal 1666

11 Teer Haar, Asas-Asas dan Susunan Hukum Adat, Jakarta: Pradnya Paramita, 1994, hlm. 210 
Perselisihan paham antara hibah dan waris terjadi karena pemahaman dari para ahli waris yang dahulu pernah mendapatkan hibah rumah tinggal dari orang tuanya jauh sebelum orang tuanya meninggal. Setelah itu orang tuanya meninggal yaitu bapak H.K Sumarman pada 1 April 2000, mereka meninggalkan 6 orang ahli waris termasuk 2 diantaranya yaitu si penerima hibah, yakni mereka anak pertama dan anak kelima. Ahli waris dari pewaris adalah 1 istri dan 6 anak, yaitu adalah dan bagian hartanya :

a. Sanaiyah (istri) mendapatkan tanah seluas $2554 \mathrm{~m}^{2}$;

b. Yusuf Hanafiah mendapatkan rumah dan tanah dengan luas $191 \mathrm{~m}^{2}$ dan sudah dihibahkan semasa H.K sunarman saat masih hidup;

c. Eni Hartini mendapatkan tanah dengan luas $500 \mathrm{~m}^{2}$;

d. Yusuf Effendi mendapatkan tanah dengan luas $500 \mathrm{~m}^{2}$;

e. Syaiful Anwar mendapatkan tanah seluas $500 \mathrm{~m}^{2}$ dan hibah rumah yang ditinggali pewaris semasa hidupnya;

f. Wiwi Iriani mendapatkan tanah dengan luas $500 \mathrm{~m}^{2}$; dan

g. Muhammad Syufri mendapatkan tanah seluas $500 \mathrm{~m}^{2}$.

Itu semua adalah bagian-bagian dari pembagian warisan setelah H.K Sunarman meninggal pada tahun 2000 dengan melalui musyawarah mufakat. Pembagian tersebut belum dilakukan proses turun waris hingga pada tahun 2007 istri dari pewaris meninggal dunia. Pada tahun 2007 istri pewaris (Ny. Sanaiyah) meninggal dunia dan disusul meninggalnya anak keempat (Syaiful Anwar). Dengan meninggalnya mereka maka, pembagian warisan yang telah ditetapkan tersebut dilakukan musyawarah ulang yang dilakukan oleh ahli waris yaitu anak pertama, kedua, ketiga, kelima dan keenam. Dari musyawarah tertanggal 1 November 2007 itu ditentukan bahwa bagian dari Ny. Sanaiyah berupa tanah 2554 M2 dijadikan harta warisan Ny. Sanaiyah. Kebetulan pada waktu ditentukan/musyawarah tanah tersebut belum bersertifikat atas nama Ny. Sanaiyah artinya, tanah peninggalan tersebut harus dilalui proses turun waris dan dibagi kepada 5 orang ahli waris. Hal tersebut dituangkan dalam surat keterangan waris yang dibuat oleh para ahli waris yaitu anak pertama, kedua, ketiga, kelima dan keenam.

Hingga pada tahun 2016 tanah itu hendak diurus pembagiannya sesuai dengan keterangan ahli waris, ternyata tanah seluas $2554 \mathrm{~m}^{2}$ peninggalan Ny. Sanaiyah telah bersertifikat atas nama anak kedua, ketiga, dan keenam. Hal tersebut diketahui setelah ada berita bahwa tanah tersebut hendak dijual, dan diketahui penjualnya adalah anak kedua, ketiga dan keenam. Terhadap kebenaran tanah tersebut bersertifikat telah dikonfirmasi kepada pihak Badan Pertanahan Nasional dan dinyatakan benar.

Anak pertama dan anak kelima menanyakan perihal kepada mereka ahli waris yang hendak menjual tanah dari Ny. Sanaiyah yaitu anak kedua, ketiga dan keenam. Alasan yang diberikan adalah anak pertama dan kelima telah menerima hibah berupa rumah dari orang tua semasa Tn. H.K Sumarman dan Ny. Sanaiyah masih hidup sehingga mereka beralasan 
keduanya tidak berhak atas tanah warisan dari ibunya. Hal itu didasari bahwa seseorang yang telah menerima hibah tidak mempunyai hak lagi terhadap warisan.

\section{Rumusan Masalah}

Berdasarkan beberapa fakta dan teori hukum diatas, penulis menarik beberapa pertanyaan hukum dengan mengambil latar belakang untuk diuraikan dan diteliti dalam permasalahan yaitu: bagaimana kedudukan ahli waris penerima Hibah terhadap ahli waris lainnya dalam harta warisan pada perspektif hukum ? apakah penerima hibah terhalang untuk menerima warisan?

\section{B PEMBAHASAN}

\section{Hibah Menurut Berbagai Perspektif Hukum}

\section{a. Hibah menurut Kitab Undang-Undang Hukum Perdata}

Dapat kita perhatikan sengketa tentang hibah dan waris dapat saja terjadi antara saudara, sesama ahli waris yang dapat merusak ikatan hubungan saudara (silaturahmi). Itu tidak dapat dipungkiri, mengingat masalah harta benda dalam kaitannya dengan warisan masing-masing ahli waris tentu mempunyai kepentingan di dalamnya. Beberapa penyebab timbulnya suatu sengketa hibah dalam keluarga pada umumnya adalah adanya niat untuk mendapatkan harta atau bagian yang lebih besar dari harta yang di tinggalkan oleh orang tuanya, karena tidak diberikan bagian sama sekali, tidak dilibatkan dalam pembagian warisan atau tidak sejalan dengan jumlah, proses dan cara pembagian. Terlebih yang sangat memprihatinkan adalah komunikasi antar saudara tidak terjalin dengan baik sehingga sejak awal sesama ahli waris memang tidak menghendaki proses pembagian warisan itu secara damai dan kekeluargaan. ${ }^{12}$

Dalam membahas kasus diatas akan diuraikan terlebih dahulu masalah-masalah tentang hibah dalam perspektif hukum. Penerapan hibah di dalam perspektif hukum di Indonesia maka mengacu pada 3 (tiga) perspektif hukum yaitu Kitab Undang-Undang Hukum Perdata, Hukum Islam dan Hukum Adat. Hal ini terjadi karena hibah merupakan kajian pada hukum perdata dan hukum perdata di Indonesia saat ini merujuk pada 3 perspektif hukum tersebut.

Kitab Undang-Undang hukum Perdata (selanjutnya disebut KUHPerdata) menjelaskan hibah pada pasal 1666 yang bunyinya : suatu perjanjian dengan mana si penghibah, diwaktu hidupnya, dengan cuma-cuma dan dengan tidak dapat ditarik kembali, menyerahkan sesuatu benda guna keperluan si penerima hibah yang menerima penyerahan itu, Undang-Undang tidak mengakui lain-lain hibah selain

12 Muhammad Saifullah, Hukum Islam Solusi Permasalahan Keluarga, Ctk. Pertama, Yogyakarta: UII Press, 2005, hlm. 205 
hibah-hibah di antara orang-orang yang masih hidup. ${ }^{13}$ Dalam pasal ini dijelaskan bahwa hibah adalah suatu perjanjian yang dimana itu dilakukan semasa pemberi hibah masih hidup dan itu dilakukan dengan dasar cuma-cuma ketika diserahkan. Dikatakan cuma-cuma karena pemberian hibah ini tidak mungkin dapat dicela oleh keluarga atau orang lain terhadap suatu pemberian, mengingat pemberi hibah berhak untuk mengelola harta kekayaannya dan leluasa untuk memberikannya kepada siapapun. ${ }^{14}$

Dalam KUHPerdata diutarakan bahwa hibah mempunyai hubungan yang erat dengan waris, hal ini disebabkan karena perilaku hibah adalah sama-sama memberikan pemasukan (inbreng). ${ }^{15}$ Maksud inbreng diatas disamakan pada pasal 1086 - 1099 KUHPerdata yang artinya perhitungan pemasukan itu harus dilakukan ahli waris keturunan dari orang yang meninggalkan harta warisan. Mereka adalah anak, cucu dan seterusnya kebawah kecuali mereka bila orang yang meninggalkan harta warisan secara tegas membebaskan dari perhitungan ini. Oleh karena itu perhitungan ini patut dilaksanakan oleh ahli waris lainnya, tentunya bila dikehendaki oleh orang yang meninggalkan harta warisan. Oleh karena itu berdasarkan KUHPerdata maka orang tua yang memberikan harta hibah kepada anaknya, pemberian tersebut dapat dikatakan dengan pemasukan (inbreng). Konsekuensinya adalah anak tersebut dianggap telah menerima warisan atau diperhitungkan sebagai warisan.

Kenapa hal ini dapat terjadi ?, pemahaman seperti ini merujuk pada sistem waris ab-intestato ${ }^{16}$ dimana ada hubungan langsung keturunan antara pewaris dan ahli waris sehingga penghitungan hibah sebagai harta warisan dimaksudkan untuk memudahkan dalam penghitungan pembagian warisan. ${ }^{17}$ Artinya hibah yang telah diberikan sebelumnya tersebut dapat disikapi sebagai bentuk uang muka dalam konteks bagian waris bila pemberi hibah meninggal dunia. Karena proses pemberian hibah pada konteks ini adalah pemberian hibah dari si pewaris kepada ahli waris (ayah ke anaknya). Oleh karena itu pemberian hibah dari hubungan darah, seperti orang tua kepada anaknya dapat diperhitungkan sebagai warisan kedepannya baik itu dianggap secara penuh atau dengan syarat. Syarat yang dimaksud seperti yang ada pada pasal 1672 yang bunyinya penghibah

13 Hartono Soerjopratiknjo, Hukum Waris Testamenter, Ctk. Kedua, Yogyakarta: Seksi Notariat Fakultas Hukum Universitas Gajah Mada Yogyakarta, 1984, hlm. 187-188

14 Abdul Manan, Pokok-Pokok Hukum Perdata, Ctk. Ke- 4, Jakarta Raja: Grafindo, 2001, hlm. 118

15 Djaja S. Meliala, Hukum Perdata Dalam Perspektif BW, Ctk. Pertama, Bandung: Nuansa Aulia, 2014, hlm. 224

16 Maksudnya adalah bila pemberi hibah memiliki hubungan darah, apabila kedepan pemberi hibah meninggal maka otomatis ia menjadi pewaris sedangkan penerima hibah menjadi ahli waris

17 Mohammad Idris Ramulyo, Beberapa Masalah Pelaksanaan Hukum Kewarisan Perdata Barat, Ctk.Pertama, Jakarta: Sinar Grafika, 1993, hlm. 63 
boleh memberi syarat bahwa barang yang dihibahkannya itu akan kembali kepadanya bila orang yang diberi hibah atau ahli warisnya meninggal dunia lebih dahulu dari penghibah, tetapi syarat demikian hanya boleh diadakan untuk kepentingan penghibah sendiri.

Hibah sendiri memungkinkan untuk dapat ditarik kembali oleh si pemberi hibah. Hal ini sesuai dengan KUHperdata pasal 1688: ${ }^{18}$

1) Karena syarat-syarat resmi untuk penghibahan tidak dipenuhi.

2) Jika orang yang diberi hibah telah bersalah melakukan atau membantu melakukan kejahatan lain terhadap penghibah.

3) Penerima hibah menolak memberi nafkah atau tunjangan kepada penghibah, setelah penghibah jatuh miskin.

Apabila hibah ditarik kembali maka hibah yang sudah diberikan itu harus dikembalikan kepada pemberi hibah. Tentunya penarikan (pembatalan) hibah ini harus melalui prosedur di pengadilan sebagai jalan penegakan hukum. Berdasarkan KUHPerdata pelaksanaan hibah harus melalui prosedur akta otentik. Artinya proses pemberian hibah harus dibuktikan dengan akta notaris, bila tidak maka itu menjadi batal. Pasal 1683 berbunyi : "tiada suatu hibah mengikat penghibah, atau menerbitkan sesuatu akibat yang bagaimanapun, selain mulai hari penghibahan itu dengan kata-kata yang tegas telah diterima oleh si penerima hibah sendiri atau oleh seorang yang dengan suatu akta otentik oleh si penerima hibah itu telah dikuasakan untuk menerima penghibahan-penghibahan yang telah diberikan kepada si penerima hibah atau akan diberikan kepadanya di kemudian hari. Jika penerimaan tersebut tidak telah dilakukan didalam surat hibah sendiri, maka itu akan dapat dilakukan didalam suatu akta otentik teremduian, yang aslinya harus disimpan, asalkan yang demikian itu dilakukan di waktu si penghibah masih hidup, dalam hal mana penghibahan, terhadap orang yang belakangan disebut ini, hanya akan berlaku sejak hari penerimaan itu diberitahukan kepadanya". ${ }^{19}$

Dijelaskan perlu adanya akta otentik dalam melakukan hibah adalah karena secara esensi-nya hibah harus dalam akta otentik, bukan sekadar alat bukti semata. Mengingat hibah adalah pemberian sepihak yang akan berkaitan dengan ahli waris dari pemberi hibah, maka perlu adanya akta otentik.

b. Hibah menurut hukum adat

Secara sederhana hibah menurut hukum adat dijelaskan dengan pembagian harta peninggalan diwaktu pemiliknya masih hidup dan diberikan kepada keluarganya. ${ }^{20}$ Hal ini diungkapkan Teer Haar bahwa hibah dilakukan semasa si pemberi hibah masih hidup.

18 Subekti. R, Kitab Undang-Undang Hukum Perdata, Ctk. Ke-34, Jakarta: Pradnya Paramita, 2004, hlm. 440

${ }_{19}$ Raden Soebekti, Kitab Undang-Undang Hukum Perdata, Ctk. Ke-34, Jakarta: Pradnya Paramita, 2004, hlm. 438-439

20 Teer Haar, Asas- asas dan Susunan Hukum Adat, Jakarta: Pradnya Paramita, 1994, hlm. 210 
Dijelaskan lebih lanjut bahwa hibah ini merupakan pemberian sukarela kepada orang lain tanpa adanya sebuah imbalan apapun. Adapun tujuan adanya hibah menurut adat secara tidak langsung adalah untuk mencegah terjadinya perselisihan, keributan, atau perselisihan yang timbul karena pembagian harta peninggalan dari orang tua pada kemudian hari. ${ }^{21}$ Jadi harapan adanya pemberian hibah diawal adalah untuk menghindari perselesihan dari para anggota keluarga kedepannya karena semua bagian-bagiannya sudah dibagikan.

Hibah pada perspektif hukum adat biasanya dilakukan dengan memberikan kepada anak karena dengan pertimbangan bahwa anak nanti yang akan menerima haknya dikemudian hari. Seperti misalnya menghibahkan tanah pertanian untuk dikelola, hewan ternak untuk dipelihara, rumah untuk dihuni, kebun untuk dikelola. Pemberian semacam ini belum dapat diberikan kepada anak yang paling akhir (bungsu) karena biasanya anak bungsu masih tinggal sama orang tuanya. Ada beberapa kebiasaan hukum adat dimana bagian anak bungsu terkadang lebih besar dari anak-anak lainnya akan tetapi, bisa jadi bagian yang lebih besar itu karena ia memiliki tanggung jawab yang lebih besar dibanding anak-anak lainnya dalam mengurus orang tuanya. $^{22}$

Masih dalam perspektif hukum adat pada konteks hibah, orang tua terikat pada apa yang dilakukannya artinya, semua anak berhak atas harta peninggalan orang tuanya. Hanya saja bagaimana cara membaginya, itu sepenuhnya diberikan kebebasan kepada orang tua untuk menentukan besar kecilnya bagian. Pada konteks ini, Teer Haar berpendapat bahwa walaupun orang tua bebas menentukan bagian hibahnya kepada anak-anaknya, tetapi pembagian itu harus dilakukan merata, yakni semua anak mendapat bagian semuanya. ${ }^{23}$ Kemudian agar nanti tidak merugikan porsi dari para ahli waris yang lain maka pembagian atau pemberian hibah itu harus dilakukan sewajarnya. ${ }^{24}$

Untuk memudahkan pemahaman hibah pada konteks hukum adat maka sasaran hibah yang dapat diberikan antara lain :

1. Mereka yang menerima barang-barang harta itu adalah ahli waris, yaitu anak dan isteri.

2. Orang tua yang mewariskan itu meskipun, terikat oleh peraturan bahwa segala anak harus mendapat bagian yang layak hingga tidak diperbolehkan melenyapkan hak waris sesuatu anak akan tetapi, orang tua mempunyai kebebasan dalam menetapkan

21 Soerojo Wignojodipoero, Pengantar dan Asas-Asas Hukum Adat, Toko Gunung Agung, Jakarta, 1995, hlm. 204

22 Nico Ngani, Perkembangan Hukum Adat Indonesia, Ctk. Pertama, Yogyakarta: Pustaka Yustisia, 2012, hlm. 48

23 Teer Haar, Op.Cit., hlm. 211

24 Ramon Menik Siregar, "Fungsi Hibah Dalam Perlindungan Bagi Anak Pada Pembagian Harta Di Tinjau Dari Hukum Perdata”, Skripsi, Medan: Universitas Sumatera Utara, 2008, hlm. 17 
barang-barang manakah akan diberikan kepada anak A dan barang-barang mana kepada anak B atau kepada isteri. ${ }^{25}$

Selain pemahaman diatas, pada masyarakat hukum adat yang lain ada yang menggambarkan bahwa harta orang tua yang dihibahkan kepada anaknya maka anak-anaknya yang menerima hibah itu dianggap telah mendapatkan harta warisan. Walaupun pemberian itu masih sebatas hibah, terkadang ada pula kemenankan/saudara sepupu dari orang tua (paman) yang ingin memperoleh bagian juga. Tidak jarang antara paman dan kemenakannya berselisih terhadap bagian yang dihibahkan oleh kakaknya (kakak si paman) dan kemenakannya (anak kakaknya). Terhadap masalah seperti ini kadang si anak yang mendapatkan hibah dari ayahnya (kakak si paman) dapat memberikan juga kepada kemenakan-kemenakan dari ayahnya (paman). ${ }^{26}$

Hibah dalam hukum adat pada prinsipnya dapat ditarik kembali bila hibah yang dilakukan tersebut diberlakukan syarat atau tidak sesuai dengan ketentuan yang berlaku. ${ }^{27}$ Adapun beberapa contoh masyarakat yang memberlakukan hal tersebut antara lain seperti pada Jawa Barat terutama di Desa Leuwi Leang dan Citeureap suatu hibah dapat ditarik kembali apabila bertentangan dengan ketentuanketentuan dalam hukum adat dan Hukum Islam akan tetapi, sebaliknya didaerah cianjur, Banjar, ciamis dan cikenong suatu hibah tidak dapat ditarik kembali meskipun utang pewaris tidak dapat terlunasi dari kekayaan yang ditinggalkannya. ${ }^{28}$ Jadi pelaksanaan hibah pada hukum adat juga membuka untuk pembatalan hibah atau dapat ditarik kembali bila itu terdapat ketentuan berlaku tidak sesuai.

Pada hukum adat hibah harus dilakukan dengan pemberitahuan yang terang artinya, kerabat dan kreditor patut diberitahu walapun untuk keluarga cukup dibuktikan dengan sebuah pengakuan saja. Mengingat pola pikir hukum adat yang konkret dan nyata hibah dan masalah penyerahan harta peninggalan juga harus jelas diawal oleh mereka yang nantinya akan menjadi ahli waris. ${ }^{29}$ Kebiasaan masyarakat pada umumnya harta seorang laki-laki yang meninggal tidak langsung dibagikan, selama masih ada janda (isteri) atau anakanak yang masih kecil, ada juga sebaliknya ada masyarakat yang membagikan harta ketika kedua orang tua mereka masih hidup. ${ }^{30}$

25 Ibid., hlm. 35

26 Kejadian seperti ini terjadi pada masyarakat hukum adat di Minangkabau lihat pada Chairul Anwar, Hukum Adat Indonesia Meninjau Hukum Adat Minangkabau, Ctk. Pertama, Jakarta: Rineka Cipta, 1997, hlm. 91

27 Azni, Eksistensi Hibah dan Posibiltas Pembatalannya Dalam Perspektif Hukum Islam dan Hukum Positif di Indonesia, Riau: Fakultas Dakwah dan Komunikasi UIN Sultan Syarih Kasim, hlm. 100

28 Azni, Ibid., hlm.108

29 Laksanto Utomo, Hukum Adat, Ctk. Pertama, Jakarta: Raja Grafindo, 2016, hlm. 104

30 Ahmad Tholabi Kharlie, Hukum Keluarga Indonesia, Ctk. Pertama, Jakarta: Sinar Grafika, 2013, hlm. 259 
Di dalam Hukum Adat yang menganut sistem kekeluargaan parental, matrilineal dan patrilineal, apabila orang tua yang memberikan hibah kepada anaknya dapat diperhitungkan sebagai warisan. ${ }^{31}$ Dalam pemberian hibah ini dilakukan pada waktu anak menjadi dewasa dan sudah membentuk keluarga atau sudah menikah. ${ }^{32}$

Kemudian setelah orang tua yang memberikan hibah ini meninggal dunia dan akan dilakukan pembagian harta warisan maka hibah tersebut akan diperhatikan serta diperhitungkan sebagai harta warisan sehingga penerima hibah tidak lagi berhak atas harta warisan yang di tinggalkan oleh orang tuanya. ${ }^{33}$ Akan tetapi, apabila harta warisan yang ditinggalkan oleh orang tuanya tersebut cukup banyak dan ahli waris yang menerima hibah merasa belum cukup maka ia akan mendapatkan tambahan pada saat harta peninggalan orang tuanya di bagi-bagi. ${ }^{34}$ Dengan demikian terlihat hubungan antara hibah dengan warisan. Dimana hibah atau pemberian ini dapat diperhitungkan sebagai warisan.

c. Hibah menurut islam

Berbicara mengenai hibah, Islam memberikan banyak pengertian yang dapat kita temukan. Kata hibah berasal dari bahasa arab yang secara etimologis berarti melewatkan atau menyalurkan, juga bisa memberi, ${ }^{35}$ sedangkan hibah adalah kata benda dalam bentuk yang artinya pemberian. ${ }^{36}$ Menurut bahasa yang dimaksud dengan hibah adalah suatu pemberian yang lepas dari penggantian dan maksud tertentu. ${ }^{37}$ Adapun pengertian hibah secara istilah adalah suatu akad yang berisi pemberian harta milik seseorang kepada orang lain di waktu pemberi masih hidup tanpa mempunyai maksud untuk mendapatkan imbalan. ${ }^{38}$ Apabila, seseorang memberikan hartanya kepada orang lain dengan maksud untuk memberikan manfaat kepada orang yang diberikan tersebut akan tetapi, tidak diberikan kepada orang tersebut hak kepemilikan maka harta yang diberikan oleh pemilik harta kepada orang yang diberikan tersebut disebut dengan pinjaman. ${ }^{39}$ Ada yang menyebutkan perbuatan yang didorong dengan niat yang tulus dan tanpa pamrih, kecuali pada tuhan, pemeberian

Faizah Bafadal, Op.,Cit., hlm. 25

Azni, Op., Cit., hlm. 101

Faizah Bafadal, Op.,Cit., hlm. 26

Ibid., hlm. 27

Mardani, Hukum Kewarisan Islam di Indonesia, Ctk. Pertama, Jakarta: Raja Grafindo, 2014,

Al-Munawir, Kamus Bahasa Arab, Surabaya: Pustaka Progresif, 1997, hlm. 385

Syamsudin Muhammad Bin Muhammad Al khatib, Mugnal Muhtaz, Juz III, Beirut-Libanon: Darul Kutubuil Ilmiuyyah, 1994, hlm. 558

38 Sayyid Sabiq, Fiqhus Sunnah, Jilid III, Darul Fathi Lil'Iamil Araby, AL-Qahirah, 1410 H, hlm. 417

39 Aulia Muthiah, Hukum Islam Dinamika Seputar Hukum Keluarga, Ctk. Pertama, Yogyakarta: Pustaka Baru Press, 2017, hlm. 225 
hibah ini dilakukan oleh dari yang mempunyai harta lebih kepada yang kurang atau yang membutuhkan. ${ }^{40}$

Kompilasi Hukum Islam (KHI) pasal 211 menegaskan bahwa hibah dari orang tua kepada anaknya dapat diperhitungkan sebagai warisan. $^{41}$ Artinya, pemberian-pemberian dapat diperhitungkan sebagai warisan. Ketentuan yang seperti ini ideal, tetapi didalam kenyataannya sering menghadapi kendala, terutama yang berkaitan dengan kapan pemberian itu dapat di hitungkan sebagai warisan dan kapan pemberian itu tidak diperhitungkan sebagai warisan. Oleh karena itu, ketentuan seperti ini harus diikuti oleh ketentuan-ketentuan yang lebih rinci agar tidak timbul persengketaan sebagai akibat ketentuan yang bersifat umum itu. ${ }^{42}$

Tujuannya dari maksud di atas agar tidak adanya sikap orang tua melebihkan anak kesayangannya dengan anak kandungnnya yang lain sehingga terhindar dari munculnya sikap iri hati bagi anaknya yang lain dan terciptanya keadilan bahwa harta tersebut merupakan hak mereka bersama. $^{43}$ Nabi Muhammad Saw. mengatakan telah menceritakan kepada kami Utsman dan Abu Bakar, keduanya anak Abu Syaibah, secara makna mereka berkata; telah menceritakan kepada kami Abu Mu' awiyah dari Abu Malik Al Asyja'i dari Ibnu Hudair dari Ibnu Abbas ia berkata, "Rasulullah shallallahu 'alaihi wasallam bersabda: "Barangsiapa memiliki anak perempuan (atau saudara perempuan), ia tidak menguburkannya hidup-hidup, tidak menghinakannya dan tidak melebihkan anak laki-laki diatas mereka maka Allah akan memasukan dia kedalam surga". Utsman tidak menyebutkan lafadz "laki-laki". H. R. Abu Daud 44.

Hukum Perdata Islam di Indonesia mencoba mengambil jalan tengah bahwa hibah tersebut harus dihitung sebagai warisan. Ini berarti ia boleh saja menghibahkan sebagian hartanya kepada sebagian anaknya, tetapi harus diperhitungkan sebagai warisan. ${ }^{45}$ Dan apabila ia meninggal dunia maka hibah tersebut dimasukan dalam bundel warisan dengan memperhitungkan bahwa bagian warisan untuk dirinya (anak yang diberi hibah) akan dipotong jumlahnya sesuai

40 Bisma Siregar, Perkawinan Hibah dan Wasiat Dalam Pandangan Hidup Bangsa, Ctk. Pertama, Yogyakarta: Fakultas Hukum Universitas Islam Indonesia, 1985, hlm. 26-27

41 Muhammad Saifullah, Hukum Islam Solusi Permasalahan Keluarga, Ctk. Pertama, Yogyakarta: UII Press, 2005, hlm. 227

42 A. Rachmad Budiono, Pembaruan Hukum Kewarisan Islam di Indonesia, Ctk. Pertama, Malang: Citra Aditya Bakti, 1999, hlm. 184 hlm. 140

${ }_{43}$ H.A. Sukris Sarmadi, Hukum Waris Islam di Indonesia, Yogyakarta: Aswaja Pressindo, 2013,

44 Syaikh Muhammad Bin Shalih al-Utsaimin, Panduan Wakaf, Hibah dan Wasiat, Ctk. Ke-2, Jakarta: Pustaka Imam Syafi'I, 2008, hlm. 120

45 A. Rachmad Budiono, Pembaruan Hukum Kewarisan Islam di Indonesia, Ctk. Pertama, Malang: Citra Aditya Bakti, 1999, hlm. 183 
dengan jumlah hibah yang diberikan kepadanya sewaktu mayit masih hidup. $^{46}$

Sebagian ulama ada yang mengatakan bahwa pemberian kepada anak itu haruslah (wajib) sama. Maksudnya adalah pemberian yang berimbang tanpa membeda-bedakan apakah itu berdasarkan kelamin atau kondisi tertentu. ${ }^{47}$

Ada juga yang berpendapat bahwa yang dimaksud dengan adil adalah pemberian yang berdasarkan bagian waris dari masing-masing anak yaitu dua berbanding satu bagi anak laki-laki dengan anak perempuan.48 Pendapat lainnya menyatakan bahwa yang dimaksud dengan adil dalam pemberian itu adalah pemberian yang sama antara anak-anak.49 Oleh karena itu para ulama berpendapat bahwa persamaan dalam pemberian itu merupakan kewajiban yang harus dilaksanakan sedangkan pelebihan diantara mereka adalah haram.50 Akan tetapi pelebihan diantara anak itu mempunyai alasan yang dapat dibenarkan seperti, salah satu anak tersebut mempunyai kebutuhan yang sangat atau karena miskin atau karena kesibukannya dengan ilmu atau juga karena fisik dan lain-lain, maka dalam kondisi yang seperti ini pemberian yang lebih diantara anak-anaknya maka hal tersebut dapat dibenarkan. ${ }^{51}$

Oleh karena itu kalau seandainya orang tua menghibahkan sebagian hartanya dalam rangka memberikan pertolongan kepada anaknya yang lemah adalah sangat dibenarkan dalam Islam, sebab harta pemberian orang tuanya itu adalah merupakan haknya karena anaknya adalah tergolong orang yang lemah yang wajib mendapat pertolongan bukan saja pertolongan dari orang tuanya akan tetapi wajib mendapat pertolongan dari saudara kandungnya sendiri. ${ }^{52}$

Patut diperhatikan ada pendapat Imam Ahmad yang mengatakan apabila ada orang tua yang memberikan harta hibah hanya kepada satu anak saja perbuatan tersebut tidak dihalalkan karena perbuatan tersebut akan menimbulkan permusuhan dan memutuskan hubungan silaturahim yang diperintahkan Allah untuk menyambungnya. ${ }^{53}$

Merujuk pada KHI pasal 171 huruf (c) yang mengatakan bahwa ahli waris adalah orang yang mempunyai hubungan darah ataupun perkawinan dengan pewaris dan ia tidak terhalang karena hukum sebagai ahli waris. Ditambahkan pada pasal 174 KHI bahwa mereka

46 Ibid., hlm. 184

47 Syaikh Muhammad Bin Shalih al-Utsaimin, Op.Cit., hlm. 121 hlm. 143

Abdul Ghofur Anshori, Filsafat Hukum Kewarisan, Ctk. Ke-2, Yogyakarta: UII Press, 2010,

49 Syaikh Muhammad Bin Shalih al-Utsaimin, Op.Cit., hlm. 125

Aullia Muthia, Hukum Islam, Ctk. Pertama, Yogyakarta: Pustaka Baru Press, 2017, hlm. 231

1 Ramon Menik Siregar, Op.Cit., Hlm. 34

52 Syaikh Muhammad Bin Shalih al-Utsaimin, Op.Cit., hlm. 122

53 "Hukum Menghibahkan Semua Harta dan Melebihkan Untuk Anak", http://www.jadipintar.com/2014/11/hukum-menghibahkan-semua-harta-dan-Melebihkan-Untuk-AnakTerten tu.html, 
yang menjadi ahli waris adalah anak, bapak, nenek, cucu, dan paman. Oleh karena itu walaupun disini penulis berpendapat bahwa penerima hibah dalam hal waris ia dijelaskan dapat menjadi ahli waris menurut KHI, sedangkan dipertegas pada pasal 211 pemberian hibah dapat dipertimbangkan sebagai warisan. Kata dipertimbangkan pada pasal 211 ini yang kemudian patut disikapi oleh para ahli waris didalam menentukan bagian-bagian dalam pembagian waris.

Tabel 1.

Perspektif Hibah Pada Hukum Perdata

\begin{tabular}{|c|l|l|l|l|}
\hline \multicolumn{5}{|c|}{ PENERAPAN HIBAH } \\
\hline No & KUHPerdata & Adat & Islam & parameter \\
\hline \multirow{2}{*}{1} & $\begin{array}{l}\text { Pasal 1666 } \\
\text { pemberian } \\
\text { Cuma-Cuma } \\
\text { semasa hidup }\end{array}$ & $\begin{array}{l}\text { Pemberian sukarela, } \\
\text { diutamakan pada } \\
\text { keluarganya dengan } \\
\text { tujuan menghindari } \\
\text { perselisihan } \\
\text { dikemudian hari }\end{array}$ & $\begin{array}{l}\text { Pemberian } \\
\text { dengan niat } \\
\text { tulus } \\
\text { mengharap } \\
\text { ridho tuhan }\end{array}$ & Pengertian \\
\hline \multirow{2}{*}{2} & $\begin{array}{l}\text { Mempunyai } \\
\text { hubungan } \\
\text { erat dengan } \\
\text { waris } \\
\text { sehingga } \\
\text { diperhitung } \\
\text { kan dalam } \\
\text { inbreng } \\
\text { (pemasukan) }\end{array}$ & $\begin{array}{l}\text { Anak yang menerima } \\
\text { hibah dari orang } \\
\text { tuanya dianggap } \\
\text { telah mendapat- kan } \\
\text { harta warisan } \\
\text { (diperhitungkan) }\end{array}$ & $\begin{array}{l}\text { Kasal 211 dapat } \\
\text { diperhi } \\
\text { tung kan } \\
\text { sebagai } \\
\text { warisan }\end{array}$ & $\begin{array}{l}\text { Hubungan } \\
\text { dengan } \\
\text { warisan }\end{array}$ \\
\hline
\end{tabular}

Dari gambaran diatas dapat diketahui secara konseptual hukum bahwa penerima hibah yang didapatkan dari orang tua mereka maka diperhitungkan sebagai warisan. Dari gambaran diatas dapat diperhatikan bahwa secara hukum (normatif), secara kebiasaan masyarakat (adat) dan secara pemahaman fiqih ke-Islaman seorang anak penerima hibah dari orang tuanya maka penerimaan itu diperhitungkan sebagai warisan kelak. Karena pemberian orang tua kepada anaknya adalah suatu hak yang harus diterima, sama hal nya dengan waris yang terjadi dimana bagian warisan adalah hak mutlak yang pasti diterima seorang anak. Tentunya hak tersebut sepanjang tidak ada halangan hukum yang menghalanginya.

\section{SIMPULAN}

Berdasarkan permasalahan dan hasil pemahaman dalam bentuk analisis dari 3 kontekstual tentang hibah pada hukum perdata di Indonesia maka kedudukan seorang penerima hibah secara hukum dan kebiasaan masyarakat di Indonesia pada umumnya secara tidak langsung diperhitungkan telah menerima harta warisan. Kitab Undang-Undang Hukum Perdata menganggap itu mempunyai hubungan erat dengan waris, sehingga diperhitungkan sebagai suatu pemasukan bagi harta peninggalan, pada hukum adat sendiri itu dianggap telah mendapatkan warisan, pada perspektif fiqih islam dan KHI itu dapat diperhitngkan sebagai 
warisan. Jadi berdasarkan hukum perdata, seorang penerima hibah yang menerima hibah itu langsung dari orang tuanya maka penerimaan tersebut diperhitungan sebagai warisan kelak.

Kedudukan si penerima hibah dari orang tua pada penjelasan hibah dari 3 perspektif hukum perdata tidak menjadikan ia terhalang untuk menerima waris. Hanya saja, penerima hibah dianggap telah mendapatkan warisan. Penerima hibah tidak terhalang hanya, hasil penerimaan hibah dari orang tua, terhitung sebagai warisan sehingga kelak ia dapat saja menerima warisan dari orang tuanya saat orang tuanya meninggal.

Fakta yang terjadi pada obyek penelitian ini dua anak dari pewaris sebelumnya telah mendapatkan hibah dari orang tuanya ketika orang tuanya masih hidup. Pada saat orang tuanya meninggal sepatutnya ahli waris saling mengutarakan bahwa ada ahli waris yang sebelumnya telah mendapatkan hibah dari orang tuanya sehingga ketika musyawarah pembagian harta warisan dari orang tua dapat dipertimbangkan dalam membuat surat keterangan waris. Fakta yang terjadi pada obyek penelitian ini pembagian itu sudah dituangkan dalam surat keterangan waris sehingga ada hal disimpangi oleh ahli waris yang bukan penerima hibah ketika mereka merasa ahli waris yang menerima hibah itu tidak mendapatkan bagian warisan. Sepatutnya dalam surat keterangan pembagian harta warisan dapat diperhitungkan dan ditentukan dengan jelas berapa bagian yang diterima ahli waris penerima hibah. Apakah ahli waris penerima hibah akan mendapatkan harta warisan lagi, atau diperhitungkan sudah cukup atau justru tidak perlu menerima harta warisan lagi. Oleh karena itu sebelum dibuat surat keterangan pembagian harta warisan, para ahli waris perlu memperhatikan keberadaan ahli waris penerima hibah sehingga nanti ketika dituangkan dalam surat keterangan pembagian harta warisan sudah sama-sama saling menerima.

\section{DAFTAR PUSTAKA}

\section{Buku :}

Al Munawir. 1997. Kamus Bahasa Arab, Surabaya: Pustaka Progresif

Ali, Zainuddin. 2010. Pelaksanaan Hukum Waris Di Indonesia, Jakarta: Sinar Grafika

Ali, Zainuddin. 2009. Metode Penelitian Hukum, Jakarta: Sinar Grafika

Anshori, Abdul Ghofur. 2010. Filsafat Hukum Kewarisan, Yogyakarta: UII Press

Anwar, Chairul. 1997. Hukum Adat Indonesia Meninjau Hukum Adat Minangkabau, Jakarta: Rineka Cipta

Budiono, A. Rachmad. 1999. Pembaruan Hukum Kewarisan Islam di Indonesia, Malang: Citra Aditya Bakti

Fuady, Munir. 2014. Konsep Hukum Perdata, Jakarta: Raja Grafindo Persada 
Haar, Teer. 1994. Asas- asas dan Susunan Hukum Adat, Jakarta: Pradnya Paramita

Idris Ramulyo, Mohd. 1993. Beberapa Masalah Pelaksanaan Hukum Kewarisan Perdata Barat, Jakarta: Sinar Grafika

Karim, Helmi. 1997. Fiqh Muamalah, Jakarta: Raja Grafindo Persada

Kharlie, Ahmad Tholabi. 2013. Hukum Keluarga Indonesia, Jakarta: Sinar Grafika

Kitab Undang-Undang Hukum Perdata

Kompilasi Hukum Islam

Mahmud Marzuki, Peter. 2005. Penelitian Hukum, Jakarta: Prenada Media Group

Mamudji, Sri, et.al. 2005. Metode Penelitian dan Penulisan Hukum, Jakarta: Badan Penerbit Fakultas Hukum Universitas Indonesia

Manan, Abdul. 2001. Pokok-Pokok Hukum Perdata, Jakarta: Raja Grafindo

Mardani. 2014. Hukum Kewarisan Islam di Indonesia, Jakarta: Raja Grafindo

Maya, Sekar. 2013. Hukum Waris Kekeluargaan Adat, Modul, Depok: Fakultas Hukum Universitas Indonesia

Meliala, Djaja.S. 2014. Hukum Perdata Dalam Perspektif BW, Bandung: Nuansa Aulia

Mertokusumo, Sudikno. 2008. Mengenal Hukum, Yogyakarta: Liberty Yogyakarta

Muhammad Bin Muhammad Al khatib, Syamsudin. 1994. Mugnal Muhtaz Juz III, Beirut-Libanon: Darul Kutubuil Ilmiuyyah

Muhammad Bin Shalih al-Utsaimin, Syaikh. 2008. Panduan Wakaf, Hibah dan Wasiat, Jakarta: Pustaka Imam Syafi' $i$

Muthiah, Aulia. 2017. Hukum Islam Dinamika Seputar Hukum Keluarga, Yogyakarta: Pustaka Baru Press

Ngani, Nico. 2012. Perkembangan Hukum Adat Indonesia, Yogyakarta: Pustaka Yustisia

Perangin, Effendi. 1997. Hukum Waris, Jakarta: PT Raja Grafindo Persada

R, Subekti. 2004. Kitab Undang-Undang Hukum Perdata, Jakarta: Pradnya Paramita 
Sabiq, Sayyid. 1410 H. Fiqhus Sunnah Jilid III. AL-Qahirah: Darul Fathi Lil'Iamil Araby

Saifullah, Muhammad. 2005. Hukum Islam Solusi Permasalahan Keluarga, Yogyakarta: UII Press

Saifullah, Muhammad. 2005. Hukum Islam Solusi Permasalahan Keluarga, Yogyakarta: UII Press

Siregar, Bisma. 1985. Perkawinan Hibah dan Wasiat Dalam Pandangan Hidup Bangsa, Yogyakarta: Fakultas Hukum Universitas Islam Indonesia

Soekamto, Soerjono. 2007. Penelitian Hukum Normatif (Suatu Tinjauan Singkat), Jakarta: PT Raja Grafindo Persada

Soekanto, Soerjono dan Sri Mamudji. 2007. Penelitian Hukum Normatif Suatu Tinjauan Singkat, Jakarta: Raja Grafindo Persada

Soerjopratiknjo, Hartono. 1984. Hukum Waris Testamenter, Yogyakarta: Seksi Notariat Fakultas Hukum Universitas Gajah Mada Yogyakarta

Suratman dan Philips Dillah. 2014. Metode Penelitian Hukum, Bandung: Alfabeta

Utomo, Laksanto. 2016. Hukum Adat, Ctk. Pertama. Jakarta: Raja Grafindo

Wardah, Sri dan Bambang Sutiyoso. 2007. Hukum Acara Perdata dan Perkembangannya Di Indonesia, Yogyakarta: Gama Media

Wignojodipoero, Soerojo. 1995. Pengantar dan Asas-Asas Hukum Adat, Jakarta: Toko Gunung Agung

Karya Ilmiah berupa Desertasi, Tesis, Skripsi, Makalah Seminar, Lokarkarya :

Menik Siregar, Ramon,'Fungsi Hibah Dalam Perlindungan Bagi Anak Pada Pembagian Harta Di Tinjau Dari Hukum Perdata", Skripsi, 2008, Medan: Universitas Sumatera Utara 